\title{
Queering Sex Education
}

\author{
George Drazenovich \\ Lakehead University, Canada
}

\begin{abstract}
Many emancipatory efforts aimed at increasing the visibility and acceptance of lesbian, gay and transgendered youth are evident in the political and legislative life of Western society. Far from being bridges for dialogue around difference, schools are becoming sites of ideological and political conflict regarding appropriate interpretation of sexuality. Ever since the time of Dewey's seminal research in Democracy and Education what has persisted or constantly resurfaced in education has been the need to develop students' critical thinking and imbuing them with values of social life. In an increasingly diverse and pluralistic postmodern culture with its emphasis on individuality and subjectivity, imbuing students with a clear sense of shared values is challenging. Still, the formation of an ethically grounded public identity is an important objective of education. This paper discusses how queer theory, properly understood, can provide a valuable and critical approach to questions of gender and sexuality. Queer theory remains an important tool in sharpening student's analytical and critical thinking. Part of the appeal of queer theory is in the freedom it provides for students to create, build and be innovative as far as the construction of identities is concerned.
\end{abstract}

\section{Introduction}

Since the advent of the civil rights movement in the 1960's and the subsequent rise of a variety of emancipatory movements for differing ethnicities, cultures, sex and sexual orientations, controversies surrounding race, gender and sexuality have become dominant features of Western political life. In recent years sexual politics in particular has become polarized in Canada and a number of other countries. Not surprisingly, where sex education is concerned, public and even many private schools are becoming sites of controversies. Ever since the time of Dewey's seminal research entitled Democracy and Education what has persisted or constantly resurfaced in education has been the need to develop students' critical thinking an imbuing them with important public values. Education does not exist in a vacuum. The aims and objectives of education are frequently driven by economic, cultural and political considerations. Where sexual diversity is concerned, thanks to the groundbreaking work of LBGT activists there have been marked changes in the scientific and legislative domains in the past thirty years. To cite three examples; in 1987, the last vestige of homosexuality as a psychopathology under the diagnostic category of "ego-dystonic homosexuality" in the Diagnostic and Statistical Manual of Mental Disorders (DSM) was formally removed; on July 20, 2005 Bill C-38, The Civil Marriage Act, received royal assent making Canada the fourth country in the world to grant legal access to marriage for same sex couples; and in December of 2010, Title 10, $\S 654$ of the US Code for the Armed Forces popularly known as the "Don't Ask Don't Tell" policy in the United States Department of Defense was repealed making the United States in line with at least twenty-five other countries including Canada, the UK and South Africa that allow openly gay men and women serve in the military. While these efforts are now enshrined in legislation, it would be naïve to conclude that society has arrived at a consensus concerning sexuality. Various governmental departments of education, boards, trustees, educators, have sought to respond to the rapidly changing social, cultural and political landscapes by revamping sex education curriculum. These changes have resulted in mixed results. The Canadian experience is one of the more recent example of the difficulties inherent in revamping a sex education curriculum. In 2009, the province of Alberta introduced curriculum to educate students about sexuality diversity. The curriculum was met by opposition from an interfaith delegation of spiritual and religious leaders who feared that such curricula may encourage homosexuality and contradicted parents' own values. The provincial government responded to their concerns by passing Bill 44, an amendment to the Alberta Human Rights Act which permits parents to withdraw their children from classrooms where subjects of sexual orientation may be discussed. In April of 2010 the provincial government of Ontario sought to update the sex education curriculum for primary and secondary school students. As a result of backlash from parents and religious leaders who felt that the curriculum contravened their values, as well as criticism regarding the age appropriateness of the specific 
content, the Premier announced that the curriculum would not be rolled out in the fall and required a "serious rethink".

\section{Purpose}

It is evident that the curriculum of sex education is not currently addressing sexuality in such a way as to sufficiently meet the exigencies of postmodern Western culture with its emphasis on subjectivity, plurality and difference. The purpose of this paper is to discuss the role that queer theory can play within a sex education curriculum. As a critical approach to the question of gender and sexuality, queer theory is an important tool in sharpening student's analytical and critical thinking. Part of the appeal of queer theory is in the freedom it can provide for students to create, build and be innovative as far as the construction of their personal identities is concerned. The present research outlines the relevant literature related to postmodern trends in education and concerns with contemporary problematization of sexuality. Postmodern trends in education and concerns with sex education are followed by an analysis of the positive role that queer theory can play and finally identifies areas of further research and development.

\section{Literature Review}

The Canadian scholar Charles Taylor observes that the turn to the subjectivity, plurality and difference originates in the Romantic period of the nineteenth and early twentieth century. Along with this, and integral to it, there arises a generalized culture of authenticity or expressive individualism. While the ethic of authenticity originates in the Romantic period, it has utterly penetrated popular culture in the time since the Second World War if not even closer to the present [1]. The historical shift Taylor describes is one aspect of a complex historical process often referred to as the "postmodern turn" by scholars such as Best \& Kellner [2] and chronicled in a collection of essay by Seidman [3] among many others. The turn to the subject is a major theme in many postmodern theories of education. Leading educational theorists such as Greene [4] emphasize inter-subjectivity in education as a means to personal empowerment. Peters \& Besley [5] explore the implications of subjectivity for education in Subjectivity and Truth: Foucault, Education, and the Culture of Self. The primary question addressed in Peter \& Besley's work is what or who is the subject of education and what are the forms of self- constitution. The necessity to rethink questions of gender, identity and sexuality from a postmodern historical sensibility is being actively explored by theorists in the field of education. Slattery [6] for example, explores gender, ethnicity, and race in his book Curriculum Development in the Postmodern Era. McLaren [7] notes that schooling should be a process of understanding how multiple levels of identities are produced. There is no way to elude the inherent political nature of education. In 1916 John Dewey observed in his seminal research entitled Democracy and Education, that by the nineteenth century modern democratic furnished both the goals of education and the instrument of its delivery through the development of "an extensive and thoroughly grounded system of public education" [8]. Since that time schools have been tasked with delivering all manner of political, cultural and historical discourses on behalf of civil society. Those discourses include discourses on sexuality.

The term discourse has a specific meaning in critical analysis and occupies a central place in interpreting sexuality. Discourses are social, political and cultural arrangements of ideas and concepts through which the world as we know it is communicated and constructed; they are observed in terms of the elements of knowledge within them and the power they exert on human behaviour. Discourse is about the production of language and practices by particular systems that produce existential meanings that then shape our individual lives. "Sexuality" is also a discourse. As Foucault explains, we must not interpret sexuality in terms of how sex operates in practice, but rather show how sex is subordinate to sexuality as a specific political, social and cultural discourse [9]. At the beginning of his first volume in The History of Sexuality, Foucault clearly outlines that the primary issue with respect to sexuality is to account for the fact that it is spoken about, to discover who does the speaking, the positions and viewpoints from which they speak and the institutions which prompt people to speak about it. At issue, according to Foucault is the overall "discursive fact"; the way in which sex is "put into discourse." His method is to locate sexuality's forms of power, the channels it takes, and the discourses it permeates in order to reach individual modes of behaviour [10]. Explaining discursive practices, Foucault writes:

Discursive practices are not simply
ways of producing discourse. They
are embodied in technical processes,
in institutions, in patterns for
general behavior, in forms of
transmission and diffusion, and
pedagogical forms which, at once,
impose and maintain them [11]

Discourses, and the practices associated with them, are situated in particular historical and social 
contexts, they are not universal truths. Foucault locates contemporary sexual discourses as rapidly developing and multiplying in the eighteenth and nineteenth century during the so called sexually repressive Victorian era. To underscore this point, Foucault observes the usage of the term "sexuality", as Western culture tends to interpret it today, was established in the nineteenth century:

in connection with other
phenomena: the development of
diverse fields of knowledge
(embracing the biological
mechanisms of reproduction as well
as the individual or social variants
of behaviour); the establishment of
a set of rules and norms - in part
traditional, in part new - which
found support in religious, judicial,
pedagogical, and medical
institutions; and changes in the way
individuals were led to assign
meaning and value to their conduct,
their duties, their pleasures, their
feelings and sensations, their
dreams [12].

According to Foucault, a hallmark of Western culture is that we are the only civilization that has approached sex by developing a science (as opposed to an art) of sexuality which has enabled us to constrain, classify and categorize it. The science of sexuality was accomplished, Foucault argues, through the discovery in the nineteenth century of the concept of population as an economic and political problem. Institutions and bodies of science began to perceive that they were not dealing simply with subjects, or even with a people, but with a population with its specific phenomena and variables. These variables include "birth and death rates, life expectancy, fertility, state of health, frequency of illness, patterns of diet and habitation" [13]. The emergent populations that were created or "discovered" in the nineteenth century, once their contours were clearly differentiated, required administration by a variety of institutions such as clinics, hospitals, prisons and schools. Populations largely inchoate before the nineteenth century begin to appear and be placed under systems of quieter but stricter constraints and to be governed by a variety of institutions such as schools. Schools were tasked with delivering all manner of political, cultural social discourses including discourses on sexuality. The value in uncovering and exposing discourses is that they can then be thwarted or blunted.

The critical question for contemporary sex educators is how to approach sexuality in a way that honours the student as a self-constituting subject as opposed to being constituted as a sexual subject by the discursive entity of "sexuality". Instead of approaching of sexuality and sexual identity as something that medicine, psychiatry or schools needs to govern by way of the development of discursive practices, queer theory is uniquely positioned in that it approaches sexuality from a subjective perspective. In education today, an entire specialty of cultural studies called queer theory has emerged as a distinct approach to sex education. Foucault and his History of Sexuality heavily influenced queer theory. Explaining queer studies and its approach to sexuality as an identity, Kelly observes:

Foucault argues that it is not the proliferation of identities that leads to sexual liberation but, rather, the separation of acts and feelings from those identities. Instead of claiming an identity for one's desires and acts, Foucault favors using one's desires to create new pleasures, relationships, networks, and cultural and political practices. In other words, it will be liberatory to simply desire, feel, and act, to just be sexual, rather than to attach those behaviors to larger cultural meanings [14].

\section{Queer Theory: An Analysis}

The scholar who is frequently credited for inaugurating the phrase "queer theory" in academic literature is Teresa de Lauretis. De Lauretis argues that queer theory is "another discursive horizon, another way of thinking the sexual" [15]. The "queering" of gender and sexuality involves interpreting human sexuality politically, socially and culturally and subverting dominant discourses from a poststructural philosophical stance. Poststructural analysis is one of the main philosophical foundations supporting queer theory today. Turner bluntly states, "poststructuralism is queer" [16] and Pećic observes that "(to) chart all the many theorists and philosophers of the twentieth century whose work is related to and partially responsible for the queer investigations of sexuality is impossible. Poststructuralists, however, were especially influential" [17]. For poststructuralists, there is no $a$ priori, essential foundational structure of identity that is encoded in human history and consciousness. Hence identity, sexual or otherwise, within poststructuralism is a heterogeneous and incomplete process and any "temporary coherence into seemingly solid characteristics or structures is only one of subjectivity's many possible expressions. What felt solid and real may subsequently separate and reform" [18]. In the context of sex education, as Kelly explains the two basic tents of queer theory is that sex is fundamentally social. Human sexuality is 
not a biological fact, but a cultural concept. People are not born sexual beings, but learn how to become them by acting cultural roles and scripts. The second tenet of queer theory is that, although claiming a sexual or gender identity may feel liberating, such identities are also forms of social control [19]. Such an approach is unique and directly challenges the assertions of such influential psychologists such as Freud. Indeed, the French poststructuralist philosopher Irigaray was among the first to directly challenge Freud. Referencing her contrast with Freud's theory, Irigaray notes that simply because Freud took sexuality as the object of his discourse does not necessarily imply that he interpreted the role of sexualization in discourse itself [20]. Taking a cue, from feminist poststructuaral analysis such as Irigaray's, queer theory interprets sexuality as a political, cultural and social discourse. The scholar who took seriously the role of discourse for sexuality was Michel Foucault. Foucault is regarded as a pivotal figure for queer theory. Foucault's objective in the History of Sexuality is a tactical reversal of the various mechanisms of sexuality of the last 500 years. Foucault suggests that the best strategy for reversing the current discursive mechanisms of sexuality is by displacing it with an economy that will feature bodies and pleasure instead of such familiar and overworked entities as sexual identity. Indeed Foucault writes,

If identity becomes the problem of sexual existence, and if people think they have to 'uncover' their 'own identity' and that their own identity has to become the law, the principle, the code of their existence; if the perennial question they ask is 'Does this thing conform to my identity?' then, I think, they will turn back to a kind of ethics very close to the old heterosexual virility. If we are asked to relate to the question of identity, it has to be an identity to our unique selves. But the relationships we have to have with ourselves are not ones of identity, rather they must be relationships of differentiation, of creation, of innovation [21].

\section{Queering Sex Education: Discussion}

Queer theory has established itself firmly in educational theory. Introductory texts such as Jaqose's [22] Queer Theory and Introduction, trace the history and genealogy of queer theory and suggest that queer theory challenges the identity politics of gay and lesbian studies by troubling the notion that sexual orientation is an essentializing category for identity. Turner's [23], A Genealogy of Queer Theory, places queer theory in a long line of civil rights movements that emerged post World War II. Wilchins' [24] Queer Theory, Gender Theory: An Instant Primer outlines the philosophical foundations, and the strengths and limitations of the theory for constructive political action. Ford's [25] research article Queering Education from the Ground Up:Challenges and Opportunities for Educators is a valuable resource and analysis of the contribution queer theory can make to pedagogy. This is not to say that queer theory has been embraced. An often cited problem however centers on the inaccessibility of the concepts and language associated with the theory to a non-specialized, nonacademic, popular audience. As Dever writes, "if queer-theoretical scholars are limited to an exclusive, and potentially exclusionary, language in which to communicate their most important ideas, queer theory itself is drastically limited as a political tool" [26]. Consequently developments in the direction of framing queer theory as a form of artistic, creative and aesthetic development may assist in removing the veil of dense ideas and technical jargon that has kept queer theory shrouded for many people. Queer theory, in the end then, is not really about sexuality as an identity that needs to be affirmed, rejected, changed, celebrated or denigrated. Instead, the emphasis is on the forms of relations with the self, the methods and techniques by which one works them out, the exercises which one makes oneself into an object to be known and on the practices that enable one to transform their own being [27]. Clearly the details concerning how curricula can facilitate such processes are important areas for further research. The purpose of the present paper was to describe how sex education could be "queered" and what that means.

\section{Conclusion}

As a critical approach to questions related to gender and sexuality, queer theory remains an important tool in sharpening student's analytical and critical thinking. Subjectivity, individuality, and plurality are strong themes in postmodern society. Part of the appeal of queer theory is in the freedom it provides people to create, build and be innovative as far as the construction of their personal identities is concerned. Queer theory provides a basis to resist any kind of discourse from any source. As such queer theory will continue to be a powerful creative force in education today. It need not descend into anarchy and diffusion provided the emphasis remains on the creation of oneself as a subject, or work of art. Indeed, the second and third volumes of The History of Sexuality, Foucault focuses on the care of the self as a pedagogical practice for sex education. According to Foucault, in ancient Greece, when one was able to care for the self, such that one's very life was transformed into an oeuvre (a work of art), then it could be said that the individual fulfilled oneself as an "ethical subject by shaping a precisely measured conduct that was plainly visible to all and deserving 
to be long remembered" [28].

\section{References}

[1] Taylor, C. (2007). A Secular Age. Cambridge, MA: The Belknap Press of Harvard University Press. p. 299.

[2] Best \& Kellner. (1997). The Postmodern Turn. New York, NY: Guilford Publications Inc.

[3] Seidman, S. (Ed.) (1994). The Postmodern Turn: New Perspectives on Social Theory. Cambridge, U.K: Cambridg University Press.

[4] Greene, M. (1988). The dialectic of freedom. New York, NY: Teachers College Press.

[5] Peters, M.A. \& Besley, T.A.C. (2007). Subjectivity and Truth: Foucault, Education, and the Culture of Self. New York:Peter Lang Publishing.

[6] Slattery, P (2006). Curriculum Development in the Postmodern Era (Critical Education Practice). New York: Routledge.

[7] McLaren, P (2009). Critical Pedagogy: A Look at the major concepts. In A. Darder \& A. Baltodano, The Critical Pedagogy Reader Second Edition (pp. 61-83). New York:Routledge Press. p. 80.

[8] Dewey, J. (2001). Chapter 7: The democratic Conception in education. In J. Dewey, Democracy and Education (p. 85-104). Pennsylvania: Penn State. (Originally published in 1916). p. 98.

[9] Foucault, M. (1990). The History of Sexuality: An Introduction Volume 1. (R. Hurley Trans.). New York: Vintage Books. (Original work published in 1978). p. 159.

[10] Foucault, M. (1990a). The History of Sexuality: An Introduction Volume 1. (R. Hurley Trans.). New York: Vintage Books. (Original work published in 1978). p. 11.

[11] Foucault, M (1980). 'Power/Knowledge'. In C. Gordon (Ed.) L. Marshall, J. Mepham, and K. Spoer, (Trans.). Selected Interviews and Other Writings 1972- 77. New York:Pantheon. P. 200.

[12] Foucault, M. (1990b). The History of Sexuality: The Use of Pleasure Volume 2. (R. Hurley Trans.). New York:Vintage Books. (Original work published in 1985). p.4.

[13] Foucault, M. (1990a). The History of Sexuality: An Introduction Volume 1. (R. Hurley Trans.). New York: Vintage Books. (Original work published in 1978). p. 25.

[14] Kelly, R. (2008). Queer Studies. Encyclopedia of Gender and Society. SAGE Publica tions. Retrieved http://sagereference.com.ezproxy.lakeheadu.ca/gender/Arti cle_n348.html.p.1.

[15] de Lauretis, T. (1991). Queer Theory: Lesbian and Gay Sexualities. An Introduction. differences: A Journal of Feminist Cultural Studies, 3(2), iii - xviii. p.iv.
[16] Turner, W. (2000). A Genealogy of Queer Theory. Philadephia:Temle University Press.

[17] Pećić, Z. (2006). Queering Queer Theory: an Analysis of Tony Kushner.(Doctoral Thesis University of Copenhagen, 2006), Akademia. DK. p. 2.

[18] Flax, J. (1993). Disputed subjects: Essays on psychoanalysis, politics and philosophy. New York: Routledge. p. 94.

[19] Kelly, R. (2008). Queer Studies. Encyclopedia of Gender and Society. SAGE Publica tions. Retrieved http://sagerereference.com.ezproxy.lakeheadu.ca/gender/A rticle_n348.html.p.1

[20] Irigaray, L. (1985). This Sex Which is Not One. (C. Porter with C. Burke Trans.) Ithaca, NY: Cornell University Press. (Original work published in 1977). p. 153.

[21] Foucault, M (1996), Sex, Power and the Politics of Identity in S. Lotringer (Ed.) Foucault Live:Collected Interviews, 1961 - 1984. New York:Semiotext. (Original work published in 1984). p. 385.

[22] Jaqose, A. (1997). Queer Theory: An Introduction. New York: NYU Press.

[23] Turner, W. (2000). A Genealogy of Queer Theory. Philadephia:Temle University Press.

[24] Wilchins, R. (2004). Queer Theory, Gender Theory: an Instant Primer. Boston, MA: Alyson Books.

[25] Ford, T. (2004). Queering education from the ground up: Challenges and opportunities for Educators. Canadian Online Journal of Queer Studies in Education, 1(1), 1-28.

[26] Dever, C. (1999). Either/And:Lesbian Theories, Queer Theories. [Book Review: The New Lesbian Studies: Into the Twenty-first Century. Bonnie Zimmerman and Toni A. H. McNaron, eds, New York: Feminist, 1996, Lesbia and Gay Studies: A Critical Introduction. Andy Medhurst and Sally R. Munt, eds. London: Cassell, 1997, Straight Studies Modified: Lesbian Interventions in the Academy. Gabriele Griffin and Sonya Andermahr, eds. London Casse,1997, Coming out of Feminism? Mandy Merck, Naomi Segal, and Elizabeth Wright, eds. Oxford: Blackwell, 1998] GLQ: A Journal of Lesbian and Gay Studies 5 (3), 413-424. p. 416.

[27] Foucault, M. (1990b). The History of Sexuality: The Use of Pleasure Volume 2. (R. Hurley Trans.). New York: Vintage Books. (Original work published in 1985). p.30.

[28] Foucault, M. (1990b). The History of Sexuality: The Use of Pleasure Volume 2. (R. Hurley Trans.). New York: Vintage Books. (Original work published in 1985). p. 9. 